\title{
Aircraft Accident
}

National Cancer Institute

\section{Source}

National Cancer Institute. Aircraft Accident. NCI Thesaurus. Code C34341.

An accident taking place aboard, or involving, any type of aircraft. 